\title{
ROBUST GLOBAL SLIDING MODEL CONTROL FOR WATER-HULL-PROPULSION UNIT INTERACTION SYSTEMS - PART 2: MODEL VALIDATION
}

\author{
Zhixiong Li, Xinping Yan, Li Qin, Kai Cheng, J. T. Xing
}

Original scientific paper

Unexpected severe hull deformation caused by wave loads poses alignment problem to the propulsion shaft line in large scale ships, which would significantly influence the dynamical performance of the marine propulsion system. How to suppress negative disturbance imposed by the interaction between water-hull-propulsion and ensure the normal operation of the marine propulsion system is a challenging task. To address this issue, a new global sliding model control (GSMC) for marine water-hull-propulsion unit systems is proposed and investigated to obtain more accurate control performance in a series of researches. In Part 1 the GSMC controller has been developed and the bounded nonlinear model uncertainties have been derived based on the experiments and sea trial. In this work the upper boundary of $1,85 \%$ was introduced into the GSMC controller to derive the total control law realising the robust control of the marine propulsion system. Numerical simulations based on the real bulk carrier parameters show a high effectiveness of the GSMC for speed tracking, compared with the traditional sliding model controller and Proportional Integral Derivative (PID) controller. By the proposed and investigated control system in this paper may be developed a simple practical-effective robust control strategy for marine propulsion systems subject to some complex unknown uncertainties through further investigations, validations and modifications.

Keywords: global sliding model control; marine propulsion system; nonlinear control model; uncertainties in marine propulsion system; water-hullprolusion unit interactions

\section{Upravljanje izdržljivim globalnim kliznim modelom za interakcijske sustave voda-trup-pogonska jedinica - Dio 2: Potvrđivanje modela}

Izvorni znanstveni članak

Neočekivana jaka deformacija trupa uzrokovana težinom valova predstavlja problem centriranja pogonskog osovinskog voda kod velikih brodova, što bi značajno utjecalo na dinamičke performanse brodskog pogonskog sustava. Kako smanjiti negativne poremećaje nastale interakcijom između vode-trupapogona i osigurati normalni rad brodskog pogonskog sustava, predstavlja pravi izazov. U tu se svrhu nizom istraživanja predlaže i ispituje novi globalni regulator kliznog modela (GSMC) za brodske sustave voda-trup-pogon kako bi se postiglo što točnije funkcioniranje upravljačkog sustava. U dijelu 1 ovoga istraživanja razvijen je upravljački mehanizam (GSMC controller) te ustanovljene granične nesigurnosti nelinearnog modela na temelju eksperimenata i pokusne plovidbe na moru. U ovom je radu uvedena gornja granica od 1,85 \% u upravljanju regulatorom kliznog modela kako bi se dobio zakon o cjelokupnom upravljanju kojim bi se omogućilo sigurno upravljanje brodskim pogonskim sustavom. Numeričke simulacije na temelju parametara broda za rasuti teret pokazuju da je GSMC visoko učinkovit u praćenju brzine u usporedbi s tradicionalnim upravljačkim mehanizmom kliznog modela i upravljačkim mehanizmom Proportional Integral Derivative (PID). Dodatnim istraživanjima, provjeravanjima i modifikacijama može se sustavom, predloženom i ispitivanom u ovom radu, razviti jednostavna praktična-učinkovita strategija upravljanja brodskim pogonskim sustavima.

Ključne riječi: interakcije voda-trup-pogon; nelinearni upravljački model; nesigurnosti u sustavu brodskog pogona; sustav brodske propulzije (pogona); upravljanje globalnim kliznim modelom

\section{Introduction}

As widely recognized, marine propulsion system is a multi-supported large scale and massive inertia dynamic system. When installed on the hull, the reliability and operational performance of the system are susceptible to the hull deformation, the pedestals deflections and the variations of wave loading condition [1]. One of the representative issues is the alignment of shaft line [2]. Though the impact of coupling effects in this complex water-hull-propulsion system is not very obvious on the small scale ships, it cannot be ignored for the large scale ships [3]. In recent years, with the rapid development of shipping, the technical parameters of large vessels such as mammoth tankers/monster tankers, mining and storage ships for marine resources, aircraft carriers and dreadnaughts, etc., become bigger and bigger, thereby leading to an evidential increase of the interaction between the water-hull-propulsion system. Great dangers have been frequently found in these vessels in forms of severe wear of support bearings, cracks of shafts and fractures of coupling bolts, etc. [4]. The key issue is to evaluate the impact of coupling effects on the navigation performance of large scale ships. One of the challenging tasks is to investigate how to suppress negative disturbance imposed by the interaction between water-hull-propulsion and ensure the normal operation of the marine propulsion system [1], which involves control of marine propulsion systems.

The control of marine propulsion systems considering hull deformations has attracted a great attention due to the important effects of the water-hull-propulsion interactions on the dynamic characteristic of the propulsion unit. This operation condition is connected via a highly nonlinear uncertain mode, where linear operation is not possible [5]. Thus, precise speed following is one of the key challenges as this capability is adversely affected by [6] (a) the misalignment of propulsion shaft line due to the waterhull-propulsion interactions, (b) speed loss due to significant coupling between the ship hydrodynamics and propulsion force, and (c) significant variation of the wave loads. These make a traditional Proportional Integral Derivative (PID) controller difficult to obtain the desired performance of marine propulsion systems [7]. As a result of this, the robust control strategy has been studied to obtain an effective control performance of marine propulsion systems considering internal/external uncertainties and disturbances $[8 \div 10]$.

As a series research, in Part 1 we have established a global sliding mode controller (GSMC) for the marine propulsion systems with bounded nonlinear model uncertainties. For the first time, the boundary issue of the 
dynamical uncertainties of the system involving the water-hull-propulsion unit interactions was investigated and a fiducial upper boundary of $1,85 \%$ was obtained based on the marine propulsion system test-bed experiments and sea trials. In this Part 2, the validation of the newly proposed GSMC accommodating the model uncertainties for marine propulsion systems is studied. Numerical studies using the real bulk carrier parameters are completed to demonstrate the efficiency of the proposed control system.

\section{Brief description of the controller}

In the research Part 1, we have designed the GSMC controller. Herein the controller is briefly reviewed.

The marine propulsion model with nonlinear uncertainties is expressed as [1]

$\ddot{\omega}+p(t) \dot{\omega}=h(t)[Q+c(t)]$

where, $Q$ denotes the oil injection; $p(t)>0$ denotes the system uncertainty subjecting to the propulsion; $h(t)>0$ denotes the system uncertainty subjecting to the hull; $c(t)>0$ denotes the system uncertainty subjecting to wave loads. The control problem in (1) is that the engine speed $\omega$ is controlled to follow a specific speed reference by actuating the oil injection $Q$. Usually, the boundaries of $p(t)$ and $h(t)$ could be predicted by prior experience and professional knowledge while the boundaries of $c(t)$ could be estimated by access to the variation of the engine output power / torque. Then the GSMC controller is designed as

$$
\begin{aligned}
Q= & -\widehat{b}(\lambda \dot{\omega}-\dot{f})+\hat{a} \dot{\omega}-\widehat{b} D- \\
& {[\breve{b}|\lambda \dot{\omega}-\dot{f}|+\breve{a}|\dot{\omega}|+C+\breve{b}|D|] \operatorname{sat}(s) }
\end{aligned}
$$

where,

$$
\begin{aligned}
& D=-(\ddot{\tilde{\omega}}+\lambda \dot{\tilde{\omega}}), \\
& \left\{\begin{array}{l}
\widehat{a}=\frac{a_{1}+a_{2}}{2} \\
\bar{a}=\frac{a_{2}-a_{1}}{2}
\end{array}\right. \\
& \left\{\begin{array}{ll}
\widehat{b}=\frac{b_{1}+b_{2}}{2} \\
\breve{b}=\frac{b_{2}-b_{1}}{2}
\end{array},\right. \\
& \operatorname{sat}(s)=\left\{\begin{array}{cc}
\frac{s}{\varepsilon} & \frac{s}{\varepsilon} \\
\frac{s}{\varepsilon} & \mid \frac{s}{\varepsilon}<1, \\
-1 & \frac{s}{\varepsilon}<-1
\end{array}\right.
\end{aligned}
$$

where, $\tilde{\omega}$ is the speed reference, $s$ is the sliding model surface,the global sliding model function is $f=f(t)=\alpha \mathrm{e}^{-\beta t}, a$ and $b$ are boundaries of uncertainties subjecting to the propulsion and hull, respectively; $c$ is the upper boundary of the external wave loads, $\varepsilon<1$ is a small positive constant, $\lambda, \alpha$ and $\beta$ need to be specified. The saturation function $\operatorname{sat}(s)$ is used to alleviate the chattering of the sliding model surface.

\section{Numerical experiments and results}

The parameters of the propulsion system of "Anguo Shan" ship is used to establish the control object in the numerical experiments. According to the marine propulsion system in (1), the numerical model of the propulsion system of "Anguo Shan" ship in the full load condition can be described as

$$
\begin{aligned}
& \ddot{\omega}+\left[5,26+0,1 \sum_{i=1}^{10} \sin (2 \pi i f t)\right] \dot{\omega}= \\
& =\left[25,1+\sum_{i=1}^{10} \sin (2 \pi i f t)\right]\left\{Q+\left[130,6+\sum_{i=1}^{10} \sin (2 \pi i f t)\right]\right\} .
\end{aligned}
$$

Eq. (7) indicates that the uncertainties of the propulsion model are dominated by the external sea waves with the fundamental frequency, $f$. The item $\left[130,6+\sum_{i=1}^{10} \sin (2 \pi i f t)\right] \leq 140,6$ suggests the uncertainty $c(t)$ has an upper boundary of 140,6 , i.e. $1,85 \%$ of the engine power in full load condition. The fundamental frequency $f$ of the wave loads is determined by the sea condition; in regular sea condition, $f=1 \mathrm{~Hz}$, and in extreme sea condition $f=100 \mathrm{~Hz}$.

According to Section 2, the uncertainty boundaries of the propulsion system in Eq. (1) can be calculated as

$b_{1}=0,028 ; b_{2}=0,066 ; a_{1}=0,121$

$a_{2}=0,414 ; C=140,6 ; \hat{b}=0,047$;

$\breve{b}=0,019 ; \widehat{a}=0,2675 ; \breve{a}=0,1465$.

The parameters of the GSMC are set as: $\lambda=12, f(t)=s(0) \mathrm{e}^{-50 t}$.

Two cases of time-varying speed reference $\tilde{\omega}$ under regular and extreme sea conditions are investigated to evaluate the control performance of the proposed GSMC method in the numerical tests. The sinusoidal reference $\widetilde{\omega}=100 \sin (\pi t / 2)$ is used to operate the ship under flexible speeds.

\subsection{Case 1: Regular sea condition}

In this case study, the fundamental frequency $f=1$ Hz. In the proposed GSMC method, the saturation function $\operatorname{sat}(s)$ is used to alleviate the chattering of the sliding model surface. A popular way in design of the control law in Eq. (2) is the use of switch function $\operatorname{sat}(s)$ 
[11]. The control performance of the proposed control law is compared with the popular switch function based control law. The GSMC is also compared with the common sliding model controller (SMC) and the traditional PID controller. The comparison of the engine speed tracking ability is shown in Fig. 1. Fig. 2 is the local zoomed area of Fig. 1, and Fig. 3 shows the control result of the traditional PID controller.

We can see from Figs. 1 and 2 that the speed tracking abilities of the GSMC using saturation function and switch function and the SMC are satisfactory. Although the time-varying speed reference together with the coupled effect of the water, ship hull and propulsion system increase the control complexity, the proposed GSMC is able to precisely track the speed reference to achieve robust and suitable control of the propulsion system. In contrast, the control result of the PID in Fig. 3 demonstrates that the PID control fails to follow the speed reference and the controller cannot stably work.

It can be seen in Fig. 2 that the saturation function based controllers is better than the GSMC with switch function with respect to the speed tracking error. Figs. 4 and 5 give the controller output and the sliding surface of the GSMC using saturation function and switch function and the SMC, respectively.

One can note that obvious chattering can be observed in Figs. 4(b), 4(c), 5(b), and 5(c). Figs. 4 and 5 indicate that the control output and sliding model surface of the proposed method is much smoother than that of the GSMC using switch function and SMC using saturation function.

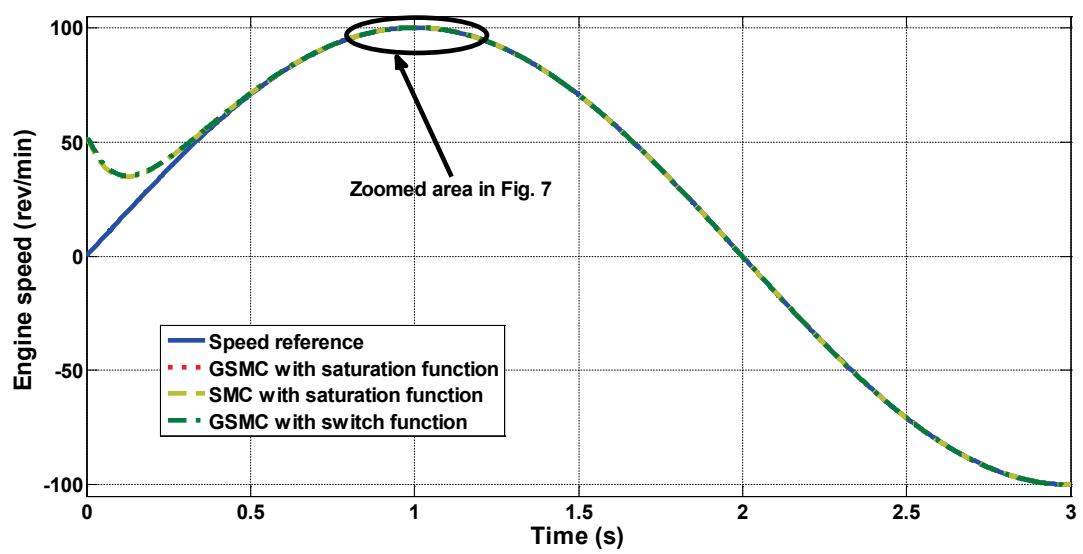

Figure 1 Comparison of the engine speed tracking performance

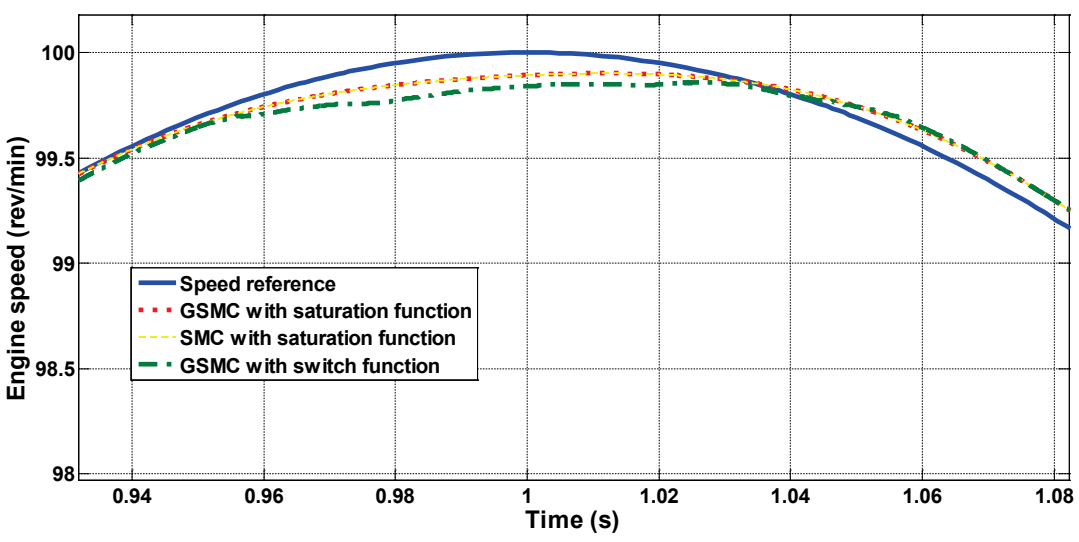

Figure 2 The zoomed picture of the marked area in Fig. 6

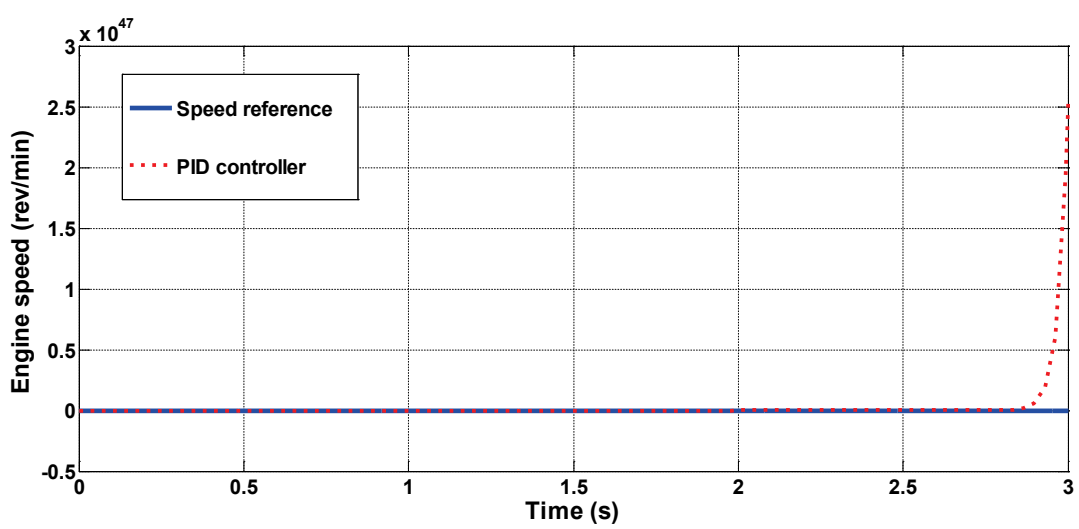

Figure 3 The speed control result of the traditional PID controller 


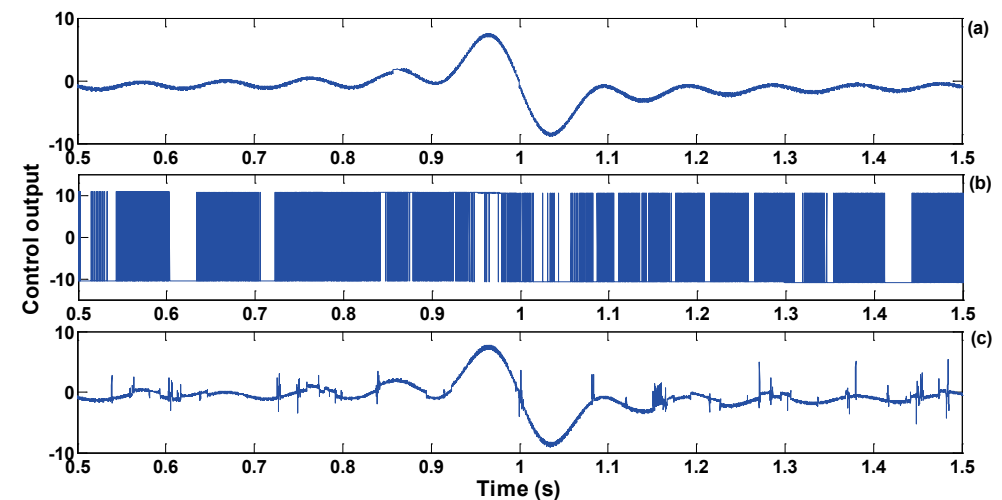

Figure 4 The control output: (a) GSMC using saturation function, (b) GSMC using switch function, and (c) SMC using saturation function

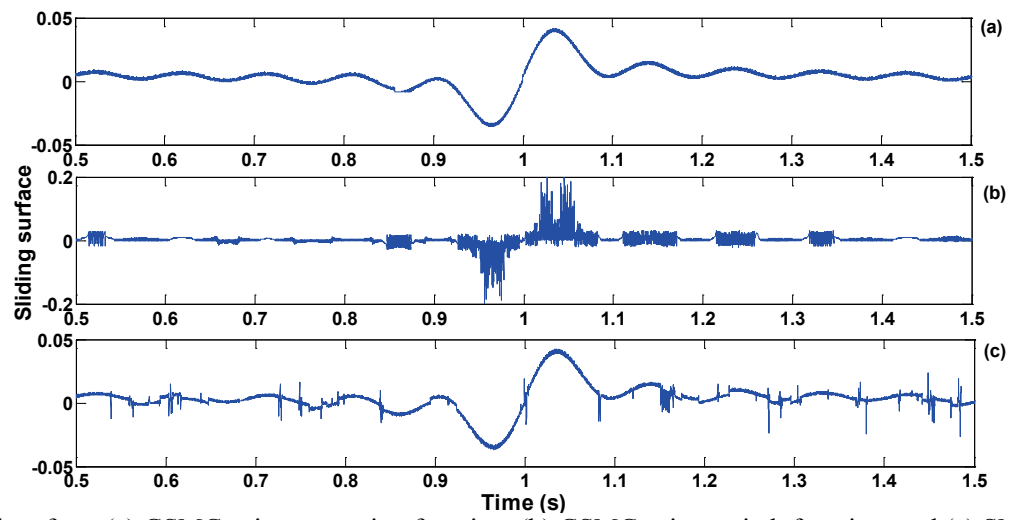

Figure 5 The sliding model surface: (a) GSMC using saturation function, (b) GSMC using switch function, and (c) SMC using saturation function

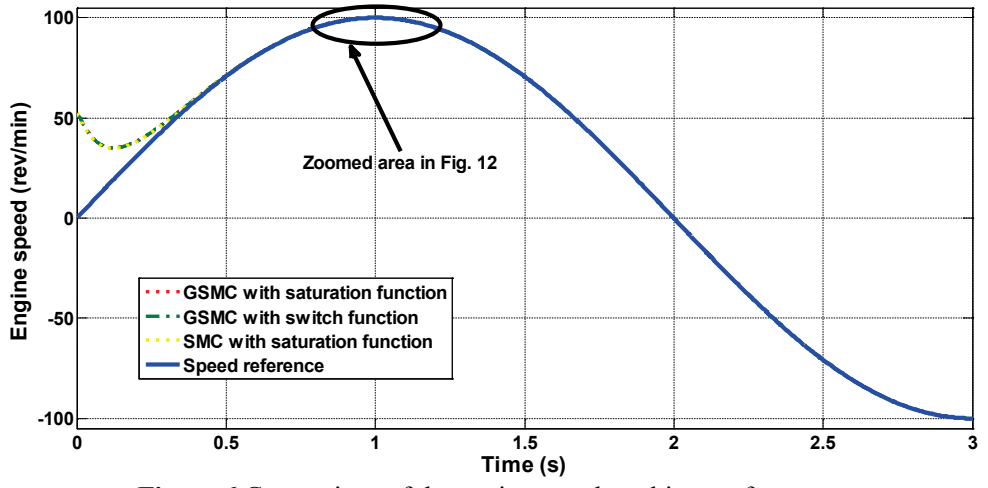

Figure 6 Comparison of the engine speed tracking performance

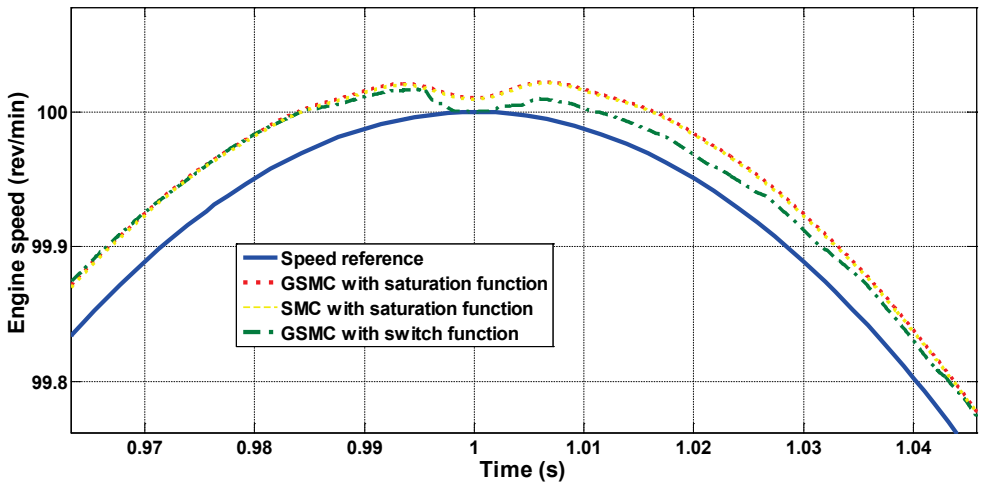

Figure 7 The zoomed picture of the marked area in Fig. 11

\subsection{Case 2: Extreme sea condition}

In this case study, the fundamental frequency $f=100$ $\mathrm{Hz}$. The comparison of the engine speed tracking ability is shown in Figs. 6 and 7, the control outputs and the sliding model surfaces are shown in Figs. 8 and 9, respectively.
It can be seen in Figs. 6 and 7 that the speed control performance is good and the three methods can track the time-varying speed reference precisely. Either average error of the compared three methods is less than 0,05 $\mathrm{rev} / \mathrm{min}$. Herein we do not present the PID control result because of the divergence of the controller. 
In Figs. 8 and 9, similar to the results in case 1, terrible chattering appears when using the GSMC with switch function and the $\mathrm{SMC}$; the proposed approach generates the best sliding surface among the compared methods and hence is more robust than the other two controllers.

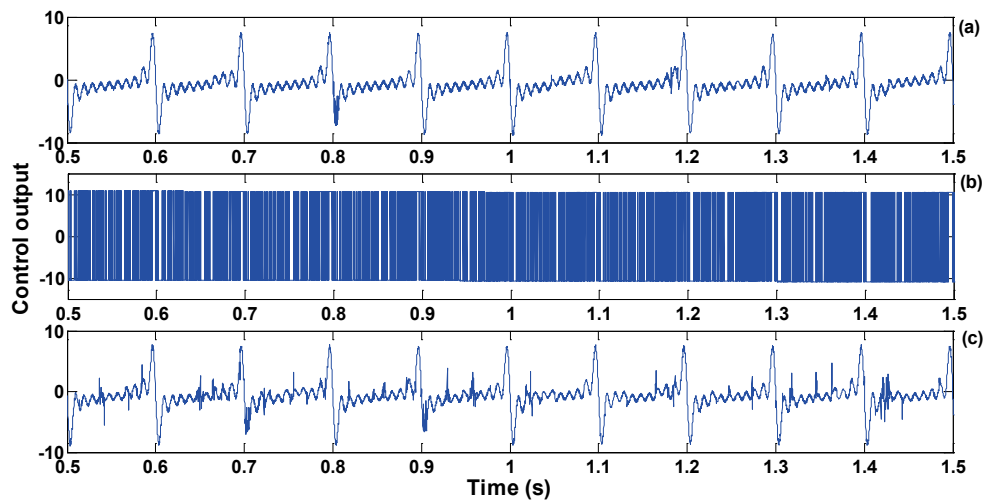

Figure 8 The control output: (a) GSMC using saturation function, (b) GSMC using switch function, and (c) SMC using saturation function

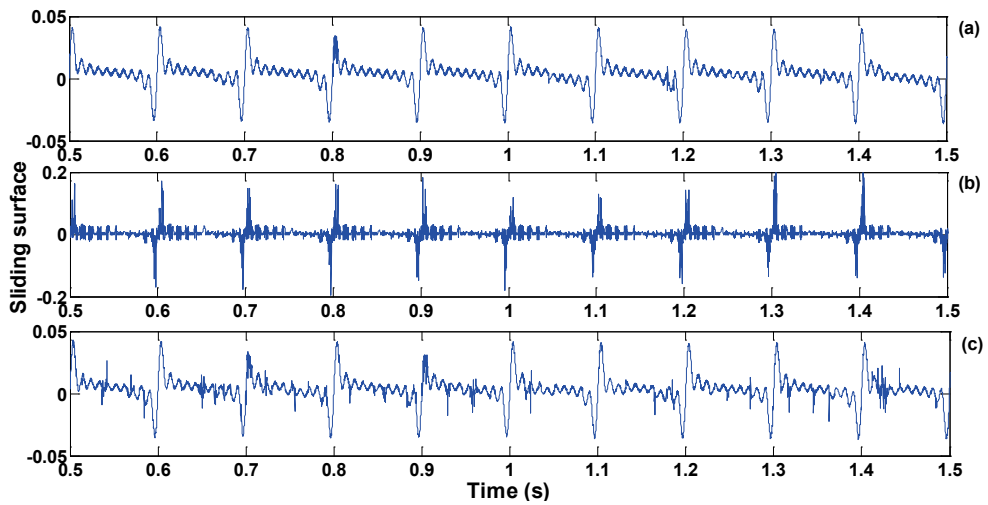

Figure 9 The sliding model surface: (a) GSMC using saturation function, (b) GSMC using switch function, and (c) SMC using saturation function

In order to highlight the proposed GSMC method, we have discussed the numerical model of the propulsion system of "Anguo Shan" ship in the $50 \%$ load condition. The uncertain model is given by

$$
\begin{aligned}
& \ddot{\omega}+\left[5,26+0,1 \sum_{i=1}^{10} \sin (2 \pi i f t)\right] \dot{\omega}= \\
& =\left[25,1+\sum_{i=1}^{10} \sin (2 \pi i f t)\right]\left\{Q+\left[65,6+\sum_{i=1}^{10} \sin (2 \pi i f t)\right]\right\}
\end{aligned}
$$

where, the item $\left[65,6+\sum_{i=1}^{10} \sin (2 \pi i f t)\right] \leq 140,6$ suggests the uncertainty $c(t)$ has an upper boundary of $1,85 \%$ of the engine power in $50 \%$ load condition. According to Section 2, the uncertainty boundaries of the propulsion system in Eq. (9) can be calculated as

$$
\begin{aligned}
& b_{1}=0,028 ; b_{2}=0,066 ; a_{1}=0,121 ; \\
& a_{2}=0,414 ; C=75,6 ; \hat{b}=0,047 ; \\
& \breve{b}=0,019 ; \widehat{a}=0,2675 ; \breve{a}=0,1465 .
\end{aligned}
$$

The parameters of the GSMC are set as:

$$
\lambda=50, f(t)=s(0) \mathrm{e}^{-150 t} .
$$

Two cases of time-varying speed reference $\tilde{\omega}$ under regular and extreme sea conditions are investigated to evaluate the control performance of the proposed GSMC method. The sinusoidal reference $\widetilde{\omega}=50 \sin (\pi t / 2)$ is used to operate the ship under flexible speeds.

\subsection{Case 3: Regular sea condition under $50 \%$ load condition}

Figs. 10 and 11 show the engine speed tracking performance of the proposed method and its rivals, Figs. 12 and 13 the control outputs and the sliding model surfaces, respectively.

The engine speed control results in Figs. 10 and 11 show that the three different SMC approaches could follow the time-varying speed reference closely. Specifically, in Fig. 11 the speed tracking performance of the saturation function based GSMC and SMC is better than the switch function based GSMC with respect to the speed tracking error.

In Fig. 12, the output of the GSMC using saturation function is vying with the other two controllers to be stable and smooth. However, in Fig. 13, it is evident that terrible oscillations of the sliding surfaces of the GSMC using switch function and SMC using saturation function appear, as well as obvious chattering. Except for small chattering, the sliding surface of the proposed method behaves stably and robustly in the whole control process. 


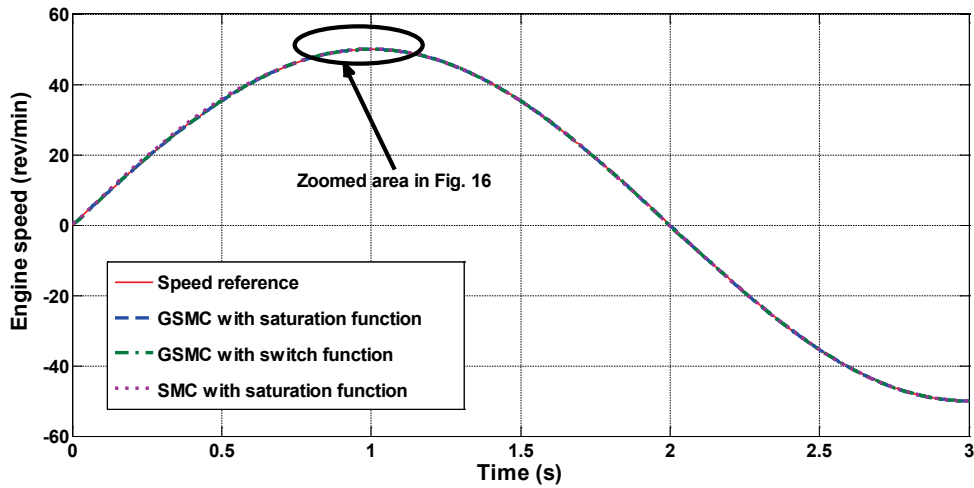

Figure 10 Comparison of the engine speed tracking performance

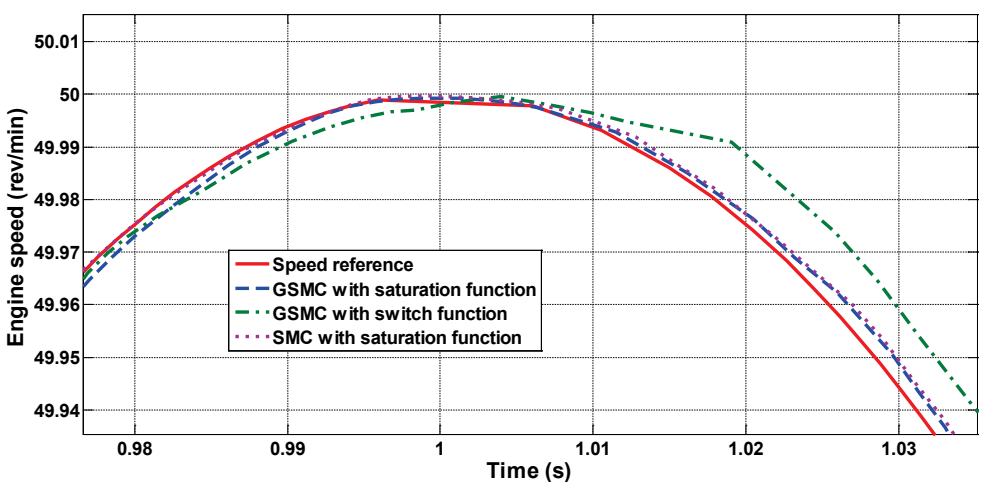

Figure 11 The zoomed picture of the marked area in Fig. 15

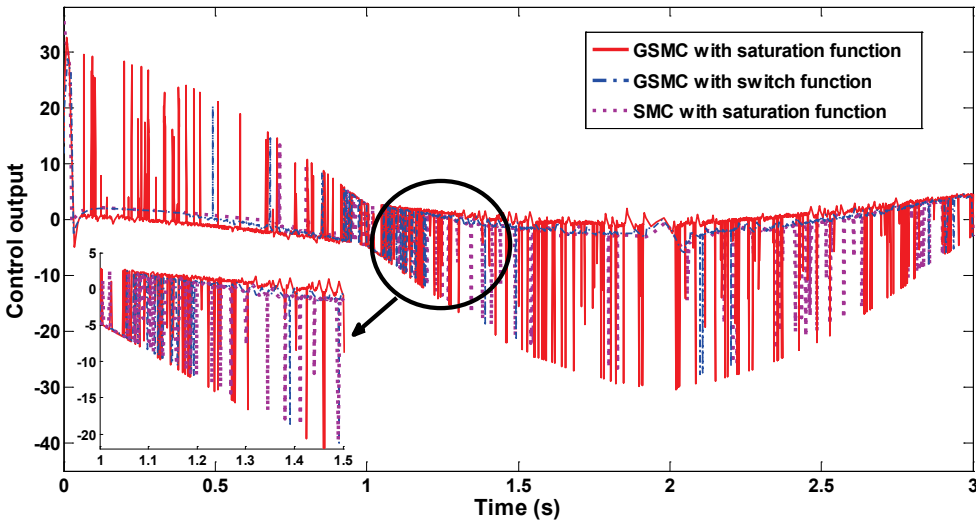

Figure 12 The control output: (a) GSMC using saturation function, (b) GSMC using switch function, and (c) SMC using saturation function

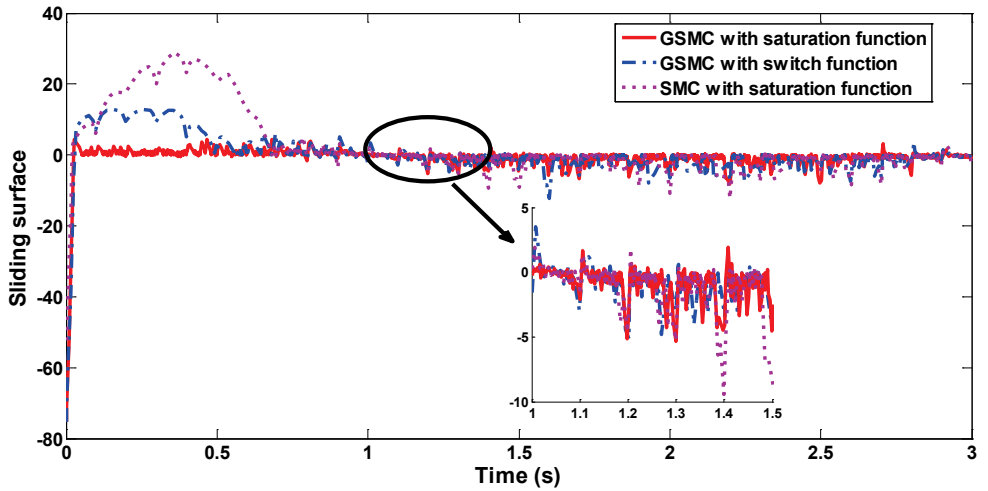

Figure 13 The sliding model surface: (a) GSMC using saturation function, (b) GSMC using switch function, and (c) SMC using saturation function

\subsection{Case 4: Extreme sea condition under $50 \%$ load condition}

The efficiency of the speed tracking of the proposed controller is evaluated by the tracking error in Figs. 14 and 15. Figs. 16 and 17 the control outputs and the sliding model surfaces, respectively.

It can be seen in Figs. 14 and 15 that the three different SMC approaches can well track the time-varying speed reference. The speed tracking error is very small for all the three approaches. In Fig. 15 the zoomed figure 
indicates that the speed tracking performance of the saturation function based GSMC and SMC outperforms the switch function based GSMC.

In Figs. 16, similarly to case 3, the outputs of the three different SMC approaches are even good while in
Fig. 17 the sliding surface of the proposed method is much better than that of its rivals. No oscillations happen using the proposed method while terrible oscillations appear twice in the sliding surface of the other two approaches.

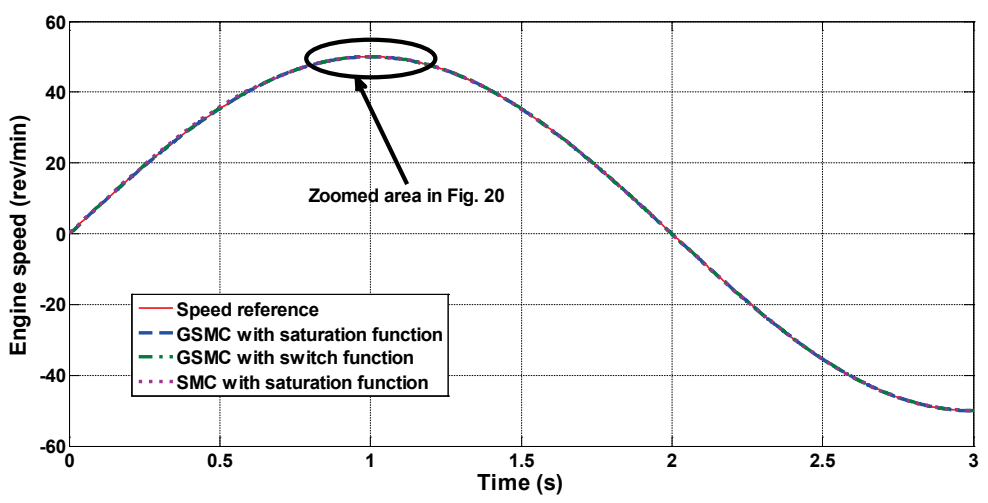

Figure 14 Comparison of the engine speed tracking performance

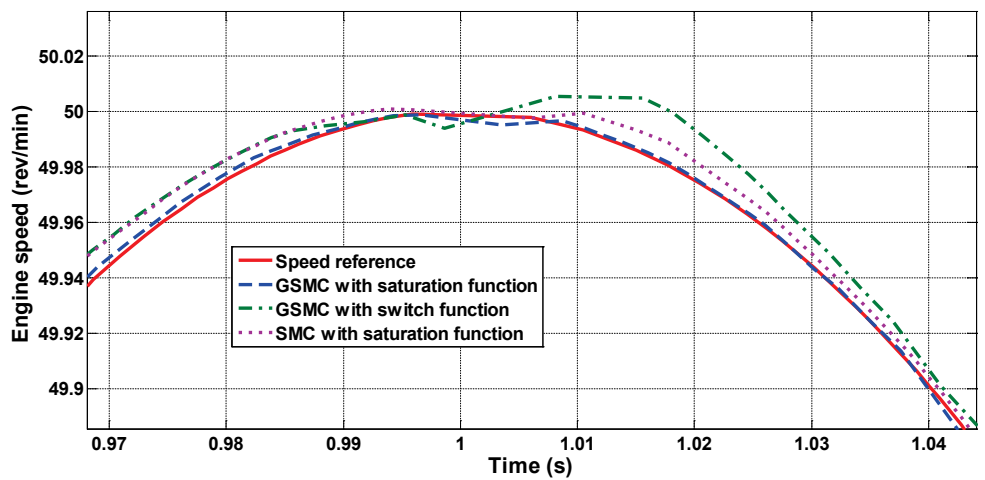

Figure 15 The zoomed picture of the marked area in Fig. 19

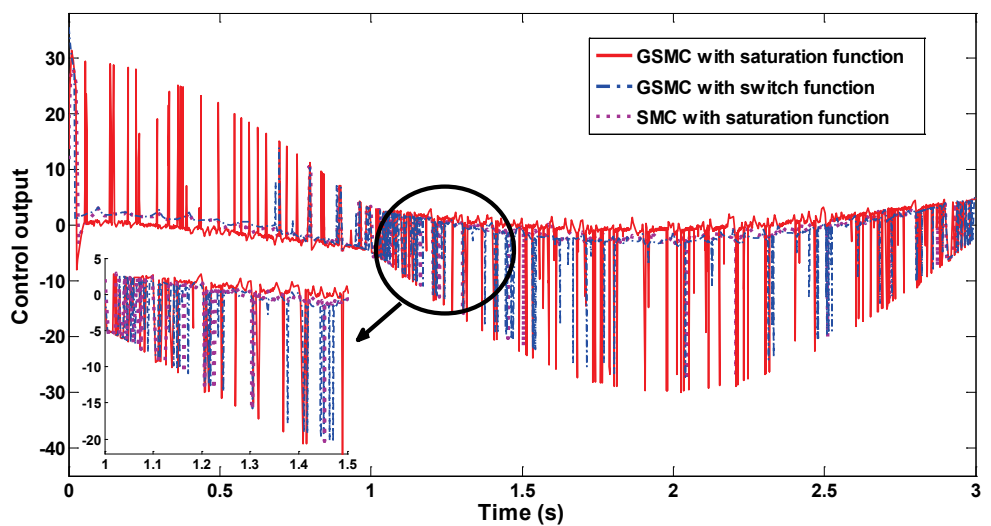

Figure 16 The control output: (a) GSMC using saturation function, (b) GSMC using switch function, and (c) SMC using saturation function

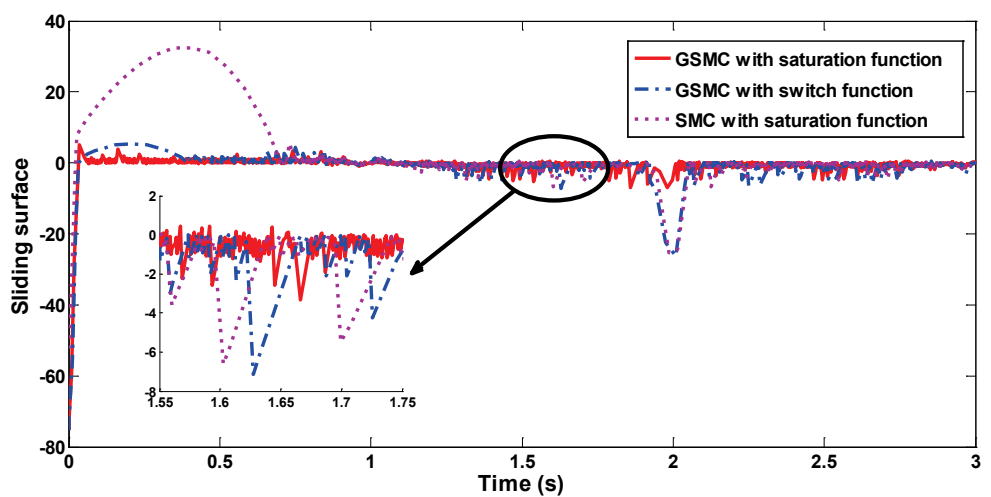

Figure 17 The sliding model surface: (a) GSMC using saturation function, (b) GSMC using switch function, and (c) SMC using saturation function 


\section{Discussion}

Although the PID controllers are widely used in the marine control systems, their control efficiency will be challenged seriously by the system model uncertainties. The numerical simulation results in Fig. 3 demonstrates that the PID control fails to follow the speed reference and the controller cannot stably work when encountering severe system uncertainties caused by the coupled effect of the water, ship hull and propulsion system. The analysis results in this work attest to that traditional PID controller cannot adapt the nonlinear model uncertainty due to the inflexibility of the PID parameters. In contrast, the strong ability of the sliding model technique in dealing with model nonlinearity and uncertainty enables the SMC based methods to follow the desired speed output accurately under varying reference orders in the marine propulsion regulation. The speed tracking performance in Figs. 1, 2, 5, 6, 10, 11, 14 and 15 in the four cases suggests high precision and strong robustness of the SMC based approaches in speed-keeping and speed-changing of the marine propulsion system. Either for regular sea condition (normal system uncertain intensity) or extreme sea condition (strong system uncertain intensity), the SMC based approaches can accurately track the given speed reference with the average speed tracking error of $0.15 \mathrm{rev} / \mathrm{min}$ or less.

In the comparison of the three SMC approaches, the results in the four cases indicate that the control robustness of the proposed method is superior to the others. In case 1, Fig. 5 shows that chattering has emerged in the sliding surfaces of the GSMC with switch function and the SMC with saturation function. The chattering has been effectively depressed in the sliding surfaces of the GSMC with saturation function. Further, in case 2 when the wave loads become stronger, in Fig. 9 the chattering has also been depressed in the sliding surfaces of the proposed method while severe chattering appears in the sliding surfaces of the other two methods. The chattering problem becomes serious in case 3 and case 4 . Severe oscillations and large chattering happen in Figs. 13 and 17 for the GSMC with switch function and the SMC with saturation function while only small chattering appears for the proposed method. This is because the proposed method not only adopts the global strategy for the sliding model but also the saturation function for the elimination of chattering problem. Hence, it will have smaller chattering than the GSMC with switch function. Since the global strategy may ensure the controller to be stable in the whole control process, it will be more robust than the SMC with saturation function. Figs. 13 and 17 have proven this point of view and the proposed GSMC method has smoother sliding surface than its rivals. As a result, the control performance of the proposed method tends to be more robust and stable than the other two methods.

Hence, the robustness of the proposed controller has been evaluated and verified by the numerical analysis. It can be seen in the design and implementation of the proposed GSMC method that only the boundaries of the system model uncertainties are involved. Compared with the model reference adaptive system (MRAS) in our previous work in [1], the proposed GSMC approach in this work does not need to set and tune the gain coefficients of the MRAS, hence the design of GSMC is simpler than the MRAS method. In addition, not only the uncertainty caused by the hull deformation is considered in this work, but also the uncertainties caused by the wave loads and propulsion dynamics. More reliable uncertain boundaries could be derived using the experiment investigation and sea trial. Hence, the proposed control method for the marine propulsion system in this work can provide a more practicable solution than that in [1].

\section{Conclusion}

The coupled effect between the water, ship hull and propulsion system has been increasing with the rapid increase of the size of the marine vessels to threaten the control efficiency of the ship speed governors. Alternative nonlinear control methodology is crucial for high performance control of the marine propulsion system under uncertainty. Taking advantage of the developed global sliding model controller (GSMC), a series of numerical tests have been carried out based on the marine propulsion control system using the parameters of the "Anguo Shan" bulk carrier. Four case studies have shown salient control performance of the proposed control approach. The proposed GSMC can operate stably and robustly on the propulsion model under time-varying speed reference orders and severe system uncertainties; the engine speed tracking error is less than $0,15 \mathrm{rev} / \mathrm{min}$. Moreover, when compared with the PID controller, the switch function based GSMC and the saturation function based SMC, the newly proposed method can achieve better control performance than its rivals.

It should be noticed that the experiments have only been carried out on "Anguo Shan" bulk carrier. In future work we plan to implement more experiments on different types of vessels to inspect the uncertainty boundaries of the marine propulsion system. More important, we will investigate the coupled control of the ship motion and ship propulsion system using the newly proposed control method, as well as the practical application of the proposed control method.

\section{Acknowledgements}

This research was funded by the the Key Program of National Natural Sciences Foundation of China (NSFC) (No. 51139005), the National Basic Research Program of China (973 Program) (No. 2014CB046300), the China Postdoctoral Science Foundation (No. 2014M551687), the Science Foundation of Jiangsu Province (No. BK20140200), the Postdoctoral Science Foundation of Jiangsu Province (No. 1402053B), the State Foundation for Studying Abroad from China Scholarship Council (NO. 201406425014), the Tribology Science Fund of State Key Laboratory of Tribology (No. SKLTKF14B05) and the Priority Academic Program Development of Jiangsu Higher Education Institutions.

\section{References}

[1] Li, Z.; Yan, X.; Qin, L.; Yuan, C.; Peng, Z. Model reference robust control for marine propulsion systems with 
model uncertainty caused by hull deformation. // Journal of Marine Science and Technology. 21, 4(2013), pp. 400-409.

[2] Schulten, $P$. The Interaction between diesel engine, ship and propeller during manoeuvring. // $\mathrm{PhD}$ thesis, Technische Universiteit Delft, Delft, Netherlands, 2005.

[3] Appolonov, E.; Nesterovand, A.; Sazonov, K. Regulation of extreme ice loads acting on hulls of azimuth propulsion systems for ice ships. // Ships and Offshore Structures. 6, 3(2011), pp. 239-247. DOI: 10.1080/17445302.2010.548124

[4] $\mathrm{Li}, \mathrm{Z}$. Investigation on the Dynamics Modeling and Condition Monitoring of the Propulsion System in Large Scale Ships. // Ph.D thesis, Wuhan University of Technology, Wuhan, 2013.

[5] Yao, W.; Yuan, L.; Zhang, J.; Chi, R.; Wei, S.; Zhang, G. Ship electrical propulsion control system based on improved model-free adaptive control. $/ / 26^{\text {th }}$ Chinese Control and Decision Conference, CCDC 2014, Changsha, China, May 31- June 2, 2014, p. 1526-1529.

[6] Belibassakis, K.; Gerostathis, T.; Politis, G. Calculation of Ship Hydrodynamic Propulsion in Rough Seas by NonLinear BEM with Application to Reduction of Energy Losses in Waves. // ASME $201332^{\text {nd }}$ International Conference on Ocean, Offshore and Arctic Engineering, Vol 5: Ocean Engineering. Nantes, France, June 9-14, 2013.

[7] Yan, X.; Li, Z.; Yuan, C.; Zhu, H.; Liu, Z. Modelling and control of marine propulsion system coupled with hull deformation. // Ship and Ocean Engineering. 40, 1(2011), pp. 60-63.

[8] Chalhoub, N.; Khaled, N. Integrated controller-observer system for marine surface vessels. // Journal of Vibration and Control. 20, 3(2014), pp. 381-394. DOl: $10.1177 / 1077546312461026$

[9] Yu, J.; Yan, Z.; Wang, J.; Li, Q. Robust stabilization of ship course via convex optimization. // Asian Journal of Control. 16, 3(2014), pp. 871-877. DOI: 10.1002/asjc.752

[10] Zhang, X.; Hu, X.; Zhao, Y.; Tang, Z. Study on application of T-S fuzzy observer in speed switching control of AUVs driven by states. // Mathematical Problems in Engineering, Vol. 2014, 2014

[11] Wai, R.; Chuang, K.; Lee, J. On-line supervisory control design for maglev transportation system via total slidingmode approach and particle swarm optimization. // IEEE Transactions on Automatic Control. 55, 7(2010), pp. 1544 1559. DOI: 10.1109/TAC.2010.2042228

\section{Authors' addresses}

\section{Zhixiong Li, $\mathrm{PhD}$}

Jiangsu Key Laboratory of Mine Mechanical and Electrical Equipment, China University of Mining \& Technology, Xuzhou 221116, China

State Key Laboratory of Tribology, Tsinghua University, Beijing 100000, China

School of Mechanical \& Manufacturing Engineering, University of New South Wales, NSW 2052 Sydney, Australia

\section{Xinping Yan, Prof. PhD}

School of Energy \& Power Engineering,

Wuhan University of Technology,

Wuhan 430063, China

Email: lzx 520@163.com

\section{Li Qin, PhD}

School of Machinery \& Automation,

Wuhan University of Science and Technology,

Wuhan 430081, China

\section{Kai Cheng, PhD}

School of Energy \& Power Engineering,

Wuhan University of Technology,

Wuhan 430063, China

\section{J. T. Xing, Prof. PhD}

WUT-UOS High Performance Ship Technology Joint Centre, Wuhan 430063, China 